\title{
A STUDY OF CUTANEOUS MANIFESTATIONS OF PATIENTS WITH PSYCHIATRIC DISORDER
}

\author{
V. Shanmugasundaram ${ }^{1}$, Sunu Joseph², Nithya $D^{3}$, Parimala $M^{4}$ \\ ${ }_{1}^{1}$ Associate Professor, Department of Dermatology, Karpagam Faculty of Medical Sciences and Research, Coimbatore, Tamilnadu. \\ ${ }^{2}$ Senior Resident, Department of Dermatology, Karpagam Faculty of Medical Sciences and Research, Coimbatore, Tamilnadu. \\ ${ }^{3}$ Assistant Professor, Department of Dermatology, Karpagam Faculty of Medical Sciences and Research, Coimbatore, Tamilnadu. \\ ${ }^{4}$ Phd Research Scholar, Department of Microbiology, Karpagam Academy of Higher Education, Coimbatore, Tamilnadu.
}

\section{ABSTRACT}

Skin is an organ that has a primary function of tactile receptivity and reacts to both external and internal emotional stimuli. Dermatological practice certainly embeds a psychosomatic dimension. A relationship between psychological factors and skin diseases has long been hypothesized.

\section{AIMS AND OBJECTIVES}

The aim of present study is to evaluate the prevalence of cutaneous manifestations in patients with psychiatric disorder.

\section{MATERIALS AND METHODS}

Twenty five psychiatric in-patients admitted in the psychiatry ward of a Tertiary Care Hospital were examined for the presence of cutaneous manifestation over a period of 6 months. Appropriate laboratory investigations such as scraping for Acarus, skin biopsy etc. were performed wherever required. The observations were noted.

\section{RESULTS}

The commonest cutaneous manifestations seen in this study were (i) Parasitic infestations like scabies (20\%), pediculosis capitis (16\%), (ii) Xerosis (28\%), (iii) Prurigo nodularis (4\%), (iv) Lichen simplex chronicus (4\%), (v) Venereophobia (4\%) and (vi) Delusion of parasitosis (4\%).

\section{CONCLUSION}

A high incidence of parasitic infestations was noted in our study. The healthcare personnel should be sensitized on the significance of such parasitic infestations in institutionalized patients and the importance of early detection and treatment.

\section{KEYWORDS}

Psychiatric Diseases, Cutaneous Manifestations of Psychiatric Diseases, Psychodermatological Disorders.

HOW TO CITE THIS ARTICLE: Shanmugasundaram V, Joseph S, Nithya D, et al. A study of cutaneous manifestations of patients with psychiatric disorder. J. Evolution Med. Dent. Sci. 2016;5(13):564-567, DOI: 10.14260/jemds/2016/129

\section{INTRODUCTION}

Skin is the largest organ of the body and determines to a great extent one's appearance and plays a major role in social and sexual communication. A psychodermatologic disorder is a condition that involves an interaction between the mind and the skin. Psychiatric diseases have a lot of cutaneous expression, like in neurodermatoses such as lichen simplex chronicus, prurigo nodularis, dermatitis artefacta, delusional parasitosis and psychogenic pruritus. Certain skin disorders may be chronic or recurrent in psychiatric patients due to the neglect, poor hygiene and noncompliance to proper treatment such as in scabies, pediculosis capitis and bacterial infections. There are very few studies on the prevalence of cutaneous disorders in patients with psychiatric diseases. Hence, this study is conducted to document the prevalence of cutaneous manifestations in patients with psychiatric disorders.

Financial or Other, Competing Interest: None.

Submission 18-01-2016, Peer Review 28-01-2016,

Acceptance 01-02-2016, Published 13-02-2016.

Corresponding Author:

Dr. V. Shanmugasundaram,

411, G. V. Residency, Sowripalayam

Coimbatore-641028, Tamilnadu.

E-mail: shanmugammd@yahoo.com

DOI: 10.14260/jemds/2016/129

\section{METHODS}

This study was conducted during a period of 6 months between March 2015 to August 2015, by the joint efforts of the Department of Dermatology and the Department of Psychiatry at a Tertiary Care Hospital. Twenty five patients irrespective of age and gender who were admitted in the psychiatry ward with a clinical diagnosis of primary psychiatric disorder were included in the study. They were examined for presence of cutaneous diseases. The presence or absence of skin lesions was noted. Appropriate laboratory investigations like scraping for fungus, scraping for Acarus and skin biopsy etc. were done wherever required. The results were tabulated.

\section{RESULT}

Out of the twenty five patients, fifteen were female and ten male. The patients were aged between 15 to 74 years. The following is the list of cutaneous manifestations seen in each of the psychiatric patient examined (Table 1)

The most common psychiatric disorders among the study population were schizophrenia (48\%), followed by Depression (16\%) and Alcohol dependence (8\%). Among the 25 patients, except two, all of them had significant cutaneous findings (i.e.) $92 \%$ of the in-hospital psychiatric patients.

The most common cutaneous presentations were Scabies (20\%), Pediculosis Capitis (16\%), Neurosis (28\%), Prurigo 
Nodularis (4\%) and Lichen Simplex Chronicus (4\%). Other conditions such as seborrheic dermatitis, traumatic injuries (8\%), delusional parasitosis (4\%) and venereophobia (4\%) were also seen (Table 1).

\begin{tabular}{|c|c|c|c|}
\hline $\begin{array}{l}\text { Sl. } \\
\text { No. }\end{array}$ & $\begin{array}{l}\text { Age/ } \\
\text { Sex }\end{array}$ & $\begin{array}{l}\text { Psychiatry } \\
\text { Diagnosis }\end{array}$ & $\begin{array}{l}\text { Cutaneous } \\
\text { Manifestations }\end{array}$ \\
\hline 1 & $40 / F$ & $\begin{array}{l}\text { Mild MR and } \\
\text { psychosis }\end{array}$ & $\begin{array}{l}\text { (i) Post-inflammatory } \\
\text { hyperpigmentation } \\
\text { (ii) Xerosis } \\
\text { (iii) Scabies }\end{array}$ \\
\hline 2 & $65 / F$ & Psychosis & $\begin{array}{l}\text { (i) Pediculosis capitis } \\
\text { with secondary } \\
\text { infections }\end{array}$ \\
\hline 3 & $71 / \mathrm{F}$ & $\begin{array}{l}\text { Moderate } \\
\text { depression and } \\
\text { somatic } \\
\text { symptoms } \\
\end{array}$ & $\begin{array}{l}\text { (i) Xerosis } \\
\text { (ii) Melasma } \\
\text { (iii) Angular cheilitis }\end{array}$ \\
\hline 4 & $15 / F$ & $\begin{array}{l}\text { Gilles de la } \\
\text { Tourette } \\
\text { syndrome with } \\
\text { mild MR and } \\
\text { severe conduct } \\
\text { disorder }\end{array}$ & $\begin{array}{l}\text { (i) Acne vulgaris } \\
\text { (ii) Seborrheic } \\
\text { Dermatitis }\end{array}$ \\
\hline 5 & $30 / \mathrm{F}$ & $\begin{array}{l}\text { Paranoid } \\
\text { schizophrenia }\end{array}$ & $\begin{array}{l}\text { (i) Pediculosis capitis } \\
\text { melasma } \\
\text { (ii) Striae distensae } \\
\text { (iii) Xerosis }\end{array}$ \\
\hline 6 & $18 / \mathrm{F}$ & $\begin{array}{l}\text { Chronic } \\
\text { schizophrenia }\end{array}$ & $\begin{array}{l}\text { (i) Lichen simplex } \\
\text { chronicus } \\
\text { (ii) Pediculosis capitis } \\
\text { (iii) Scabies }\end{array}$ \\
\hline 7 & $20 / F$ & $\begin{array}{l}\text { Moderate-to- } \\
\text { severe MR and } \\
\text { behavioural } \\
\text { disturbance } \\
\text { seizure disorder }\end{array}$ & $\begin{array}{l}\text { (i) Scabies } \\
\text { (ii) Pediculosis capitis }\end{array}$ \\
\hline 8 & $30 / F$ & $\begin{array}{l}\text { Chronic } \\
\text { schizophrenia } \\
\text { and mild MR }\end{array}$ & $\begin{array}{l}\text { (i) Seborrheic } \\
\text { dermatitis }\end{array}$ \\
\hline 9 & $36 / F$ & $\begin{array}{l}\text { BPAD-mania with } \\
\text { psychosis }\end{array}$ & $\begin{array}{l}\text { (i) Scabies } \\
\text { (ii) Xerosis } \\
\text { (iii) Pediculosis } \\
\text { capitis }\end{array}$ \\
\hline 10 & $49 / F$ & Schizophrenia & $\begin{array}{l}\text { (i) Seborrheic } \\
\text { melanosis } \\
\text { (ii) Old burns with } \\
\text { keloidal scarring } \\
\end{array}$ \\
\hline 11 & $45 / F$ & $\begin{array}{l}\text { Paranoid } \\
\text { schizophrenia }\end{array}$ & $\begin{array}{l}\text { (i) Seborrheic } \\
\text { dermatitis } \\
\text { (ii) Xerosis } \\
\text { (iii) Scabies }\end{array}$ \\
\hline 12 & $64 / F$ & $\begin{array}{l}\text { Paranoid } \\
\text { schizophrenia }\end{array}$ & $\begin{array}{l}\text { (i) Burns with post- } \\
\text { inflammatory } \\
\text { hypopigmentation, } \\
\text { (ii) Xerosis }\end{array}$ \\
\hline 13 & $29 / \mathrm{M}$ & $\begin{array}{l}\text { Alcohol } \\
\text { depression } \\
\text { syndrome }\end{array}$ & \\
\hline 14 & $38 / \mathrm{M}$ & $\begin{array}{l}\text { Paranoid } \\
\text { schizophrenia }\end{array}$ & $\begin{array}{l}\text { (i)Post-inflammatory } \\
\text { hyperpigmentation }\end{array}$ \\
\hline 15 & $50 / \mathrm{M}$ & Mild MR & $\begin{array}{l}\text { (i) Onychomycosis } \\
\text { (ii) Pityriasis capitis } \\
\text { (iii) Freckles }\end{array}$ \\
\hline 16 & $27 / \mathrm{M}$ & Schizophrenia & (i) Acne Rosacea \\
\hline 17 & $36 / \mathrm{M}$ & $\begin{array}{l}\text { Alcohol } \\
\text { repressive }\end{array}$ & $\begin{array}{l}\text { (i) Ichthyosis } \\
\text { (ii) Seborrhoea }\end{array}$ \\
\hline
\end{tabular}

\begin{tabular}{|c|c|c|c|}
\hline 18 & $36 / \mathrm{M}$ & $\begin{array}{l}\text { Paranoid } \\
\text { schizophrenia }\end{array}$ & $\begin{array}{l}\text { (i) Pityriasis capitis } \\
\text { (ii) Intertrigo toe }\end{array}$ \\
\hline 19 & $38 / \mathrm{M}$ & $\begin{array}{l}\text { Paranoid } \\
\text { schizophrenia }\end{array}$ & $\begin{array}{l}\text { (i) Insect Bite } \\
\text { Hypersensitivity }\end{array}$ \\
\hline 20 & $40 / \mathrm{M}$ & $\begin{array}{l}\text { Paranoid } \\
\text { schizophrenia }\end{array}$ & \\
\hline 21 & $37 / \mathrm{M}$ & $\begin{array}{l}\text { HIV related } \\
\text { neurocognitive } \\
\text { disorder/bipolar } \\
\text { disorder }\end{array}$ & (i) Prurigo nodularis \\
\hline 22 & $21 / \mathrm{M}$ & Depression & (i) Venereophobia \\
\hline 23 & $56 / F$ & Depression & $\begin{array}{l}\text { (i) Delusional } \\
\text { Parasitosis } \\
\text { (ii) Xerosis }\end{array}$ \\
\hline 24 & $70 / F$ & Depression & (i) Xerosis \\
\hline 25 & $40 / \mathrm{F}$ & Schizophrenia & (ii) Prurigo nodularis \\
\hline
\end{tabular}

\begin{tabular}{|c|c|c|c|}
\hline $\begin{array}{l}\text { Sl. } \\
\text { No. }\end{array}$ & Age/Sex & $\begin{array}{l}\text { Psychiatry } \\
\text { Diagnosis }\end{array}$ & $\begin{array}{c}\text { Cutaneous } \\
\text { Manifestations }\end{array}$ \\
\hline 1 & $30 / F$ & $\begin{array}{l}\text { Paranoid } \\
\text { schizophrenia }\end{array}$ & $\begin{array}{l}\text { (i) Pediculosis capitis } \\
\text { melasma } \\
\text { (ii) Striae distensae } \\
\text { (iii) Xerosis }\end{array}$ \\
\hline 2 & $18 / \mathrm{F}$ & $\begin{array}{l}\text { Chronic } \\
\text { schizophrenia }\end{array}$ & $\begin{array}{l}\text { (i) Lichen simplex } \\
\text { chronicus } \\
\text { (ii) Pediculosis capitis } \\
\text { (iii) Scabies }\end{array}$ \\
\hline 3 & $30 / F$ & $\begin{array}{l}\text { Chronic } \\
\text { schizophrenia } \\
\text { and mild MR }\end{array}$ & $\begin{array}{l}\text { (i) Seborrheic } \\
\text { dermatitis }\end{array}$ \\
\hline 4 & $49 / F$ & Schizophrenia & $\begin{array}{l}\text { (i) Seborrheic } \\
\text { melanosis } \\
\text { (ii) old burns with } \\
\text { keloidal scarring }\end{array}$ \\
\hline 5 & $45 / F$ & $\begin{array}{l}\text { Paranoid } \\
\text { schizophrenia }\end{array}$ & $\begin{array}{l}\text { (i) Seborrheic } \\
\text { dermatitis } \\
\text { (ii) Xerosis } \\
\text { (iii) Scabies }\end{array}$ \\
\hline 6 & $64 / F$ & $\begin{array}{l}\text { Paranoid } \\
\text { schizophrenia }\end{array}$ & $\begin{array}{l}\text { (i) Burns with post } \\
\text { inflammatory } \\
\text { hypopigmentation, } \\
\text { (ii) Xerosis }\end{array}$ \\
\hline 7 & $38 / \mathrm{M}$ & $\begin{array}{l}\text { Paranoid } \\
\text { schizophrenia }\end{array}$ & $\begin{array}{l}\text { (i) Post-inflammatory } \\
\text { hyperpigmentation }\end{array}$ \\
\hline 8 & $27 / \mathrm{M}$ & Schizophrenia & (i) Acne Rosacea \\
\hline 9 & $36 / \mathrm{M}$ & $\begin{array}{l}\text { Paranoid } \\
\text { schizophrenia }\end{array}$ & $\begin{array}{l}\text { (i) Pityriasis capitis } \\
\text { (ii) Intertrigo toe }\end{array}$ \\
\hline 10 & $38 / \mathrm{M}$ & $\begin{array}{l}\text { Paranoid } \\
\text { schizophrenia }\end{array}$ & $\begin{array}{l}\text { (i) Insect Bite } \\
\text { Hypersensitivity }\end{array}$ \\
\hline 11 & $40 / \mathrm{M}$ & $\begin{array}{l}\text { Paranoid } \\
\text { schizophrenia }\end{array}$ & \\
\hline 12 & $40 / \mathrm{F}$ & Schizophrenia & (ii) Prurigo nodularis \\
\hline \multicolumn{4}{|c|}{$\begin{array}{c}\text { Table 2: List of Cutaneous Manifestations } \\
\text { in Schizophrenia Patients }\end{array}$} \\
\hline
\end{tabular}




\begin{tabular}{|c|c|c|c|}
\hline $\begin{array}{l}\text { Sl. } \\
\text { No. }\end{array}$ & Age/Sex & $\begin{array}{l}\text { Psychiatry } \\
\text { Diagnosis }\end{array}$ & $\begin{array}{c}\text { Cutaneous } \\
\text { Manifestations }\end{array}$ \\
\hline 1 & $71 / \mathrm{F}$ & $\begin{array}{l}\text { Moderate } \\
\text { depression } \\
\text { and } \\
\text { somatic } \\
\text { symptoms }\end{array}$ & $\begin{array}{l}\text { (i) Xerosis } \\
\text { (ii) Melasma } \\
\text { (iii) Angular cheilitis }\end{array}$ \\
\hline 2 & $21 / \mathrm{M}$ & Depression & (i) Venereophobia \\
\hline 3 & $56 / F$ & Depression & $\begin{array}{l}\text { (i) Delusional Parasitosis } \\
\text { (ii) Xerosis }\end{array}$ \\
\hline 4 & $70 / F$ & Depression & (i) Xerosis \\
\hline
\end{tabular}

\begin{tabular}{|c|c|c|c|}
\hline $\begin{array}{l}\text { Sl. } \\
\text { No. }\end{array}$ & Age/Sex & $\begin{array}{l}\text { Psychiatry } \\
\text { Diagnosis }\end{array}$ & $\begin{array}{c}\text { Cutaneous } \\
\text { Manifestations }\end{array}$ \\
\hline 1 & $29 / \mathrm{M}$ & $\begin{array}{l}\text { Alcohol } \\
\text { depression } \\
\text { syndrome }\end{array}$ & \\
\hline 2 & $36 / \mathrm{M}$ & $\begin{array}{l}\text { Alcohol } \\
\text { repressive }\end{array}$ & $\begin{array}{l}\text { (i) Ichthyosis } \\
\text { (ii) Seborrhoea }\end{array}$ \\
\hline \multicolumn{4}{|c|}{$\begin{array}{c}\text { Table 4: List of Cutaneous Manifestations in Alcohol } \\
\text { Dependence Patients }\end{array}$} \\
\hline
\end{tabular}

\section{DISCUSSION}

Parasitic infestations like scabies and pediculosis capitis (20\% and $16 \%$ ) were by far the most common cutaneous manifestations. This can be explained by the probable lack of self awareness and self neglect by patients suffering from chronic psychiatric disorders.

Two patients had old burns with sequelae like keloidal scarring and post inflammatory hyperpigmentation. This is due to the reason that patient with psychosis may be more prone for accidents and in some case may even have self destructive behaviour and suicidal tendencies.

Venereophobia was seen in one patient with depression. Earlier studies have also shown that patients with anxiety and depression have overvalued ideas about the possibility of venereal disease including AIDS.[1]

Delusional parasitosis was also seen in one patient with depression. Delusional parasitosis affects both sexes equally below the age of 50 and is associated with schizophrenia, paranoid states, bipolar disorders, depression, anxiety disorders and obsessional states. $[2,3,4]$

The parasitic infestations like scabies and pediculosis were seen only in those patients with psychosis such as schizophrenia and bipolar affective disorder (BAPD) mania with psychosis. Those patients suffering from neurosis such as depression and substance abuse disorders like alcohol dependency did not have parasitic infestations, probably because of intact insight and better self care by these patients when compared to the psychosis patients (Table 2, 3 and 4). LSC (Lichen Simplex Chronicus) and prurigo nodularis were seen in $4 \%$ and $8 \%$ of the sample respectively. Both of these cutaneous conditions have a strong psychological trigger, which leads to insuppressible urge to scratch. Patients with LSC commonly report increased itchiness during moments of stress, anxiety or boredom. Research by Konuk et al. suggests that psychiatric symptoms may be more common in patients with LSC than in patients with other dermatoses.[5] In the study by Attah et al. the reported incidence of LSC is $11.4 \%{ }^{[6]}$ which is higher than that seen in our study, probably because of the more number of patients with anxiety involved in their study. The consensus among clinicians is that the itch of LSC is not psychogenic. But the urge to scratch may be influenced by psychological factors. According to results of a recent survey, patients with neurodermatitis reported higher levels of sexual dysfunction. [7]

In a study by Kuruvila etal. $68.66 \%$ patients had infective dermatoses and the rest had non-infective dermatoses. ${ }^{[8]}$ and the commonest infective dermatosis was tinea corporis and pityriasis versicolor. Among non-infective dermatoses, $8 \%$ had eczema and $4.67 \%$ had psychogenic skin disorders. Of these, delusions of parasitosis were the commonest (2\%) followed by venereophobia (1\%).

In the current study more of psychosis patient were seen compared to neurosis patients (Depression) in Maria Kuruvilla et al., study. The reason for higher incidence of parasitic infestation may be due to the characteristics of the sample (i.e) institutionalized patient.

Patients whose psychophysiology is expressed in cutaneous lesions often consult a dermatologist rather than a psychiatrist. According to Koeblenzer CS et al., dermatologists may not be interested in working with these difficult patients. An efficient dermatologist should be aware of the cutaneous manifestation in psychiatric disorders as it influences early diagnosis of primary psychiatric disorders. ${ }^{[9]}$

\section{CONCLUSION}

This study concludes that the prevalence of cutaneous manifestations in psychiatric patients is very high. The commonest cutaneous manifestations seen in this study are parasitic infestations such as scabies and pediculosis capitis. The prevalence of such parasitic infestations is more in patients with psychosis when compared to neurosis because of lack of insight and self neglect. Health education of psychiatric patients and/or of their caregiver and periodic monthly inspection of psychiatric patients are highly indicated for the prevention and control of infectious skin diseases in primary psychiatric patients.

\section{REFERENCES}

1. Oates JK, Gomaz J. Venereophobia. Br J Hosp Med 1984;31:435-6.

2. Lyell A. Delusion of parasitosis. Semin Dermatol 1983;2:189-95.

3. Lyell A. The Michelson Lecture. Delusion of parasitosis. $\mathrm{Br}$ J Dermatol 1983;108:485-99.

4. Hay CG. Dysmorphophobia. Br J Psychiatry 1970;116:399-406.

5. Konuk N, Koca R, Atik L, et al. Psychopathology, depression and dissociative experiences in patients with lichen simplex chronicus. Gen Hosp Psychiatry. 2007 MayJun;29(3):232-5.

6. Attah Johnson FY, Mostaghini H. Co-morbidity between dermatologic diseases and psychiatric disorders in Papua New Guinea. Int J Dermatol 1995;34:244-8.

7. Mercan S, Altunay IK, Demir B, et al. Sexual dysfunctions in patients with neurodermatitis and psoriasis. J Sex Marital Ther. 2008;34(2):160-8. 
8. Kuruvila M, Gahalaut P, Zacharia A, et al. A study of skin disorders in patients with primary psychiatric conditions. Indian J Dermatol Venereol Leprol 2004;70:292-295.
9. Koblenzer, Nayera H Moftah. Cutaneous manifestations of psychiatric disease that commonly present to the dermatologist--diagnosis and treatment. Int J Psychiatry Med. 1992;22(1):47-63. 